\title{
CULTURE AND SOCIAL ECONOMICAL SYSTEM OF SOUTHERN ARALBUYI DURING THE BRONZE AGE
}

\author{
Matyakubov Xamdam Xamidjanovich \\ Teacher at Urgench State University
}

Crossref

http://dx.doi.org/10.26739/2433-202x

Issue DOI http://dx.doi.org/10.26739/2433-202x-2017-7-7

Article DOI http://dx.doi.org/10.26739/2433-202x-2017-7-7-6

Annotation: Culture and history of social economical relations of the people of ancient Southern Aralbuyi (Southern coast of the Aral Sea) are looked through in the article.

At the result of new scientific investigations, we can observe scientific and methodical complete changes in the modern process of learning and generalizing active problems, which belong to the history of the Bronze Age in Central Asia. This situation causes the necessity of looking through scientific approaches and opinions about the ancient history of Khorezm oasis separately which were considered as superior for many years on the basis of new information.

Key words: Tozabogyob, Amirabad, Southern Aralbuyi, Central Asia, reservoir Okchadarya, M.A. Itina, S.P. Tolstov.

During the Bronze Age, groups of people in Southern Aralbuyi were adapted with the natural condition containing special features and they developed material culture and economical forms, which belonged to this geographical territory. Traditions of house building, types of labor and household tools were suitable to the life style of the native people. In this Social science and humanities

X. Matyakubov 
process, we have to take into consideration not only peculiarities of natural environment but also the development of producing power and degree of using technological innovations.

The production of agricultural goods, crafts of the society and peculiarities of works, the task of rising economical and sociable system on the basis of archeological materials and sociable and economical relations which belong to the history of the Bronze Age in Khorezm oasis haven't been learned thoroughly yet. These tasks were shortly reflected in some chapters of monographs and scientific articles.

At the result of new scientific investigations, we can observe scientific and methodical complete changes in the modern process of learning and generalizing active problems, which belong to the history of the Bronze Age in Central Asia. This situation causes the necessity of looking through scientific approaches and opinions about the ancient history of Khorezm oasis separately which were considered as superior for many years on the basis of new information.

The following problems haven't been learned till the last years and the reasons which are directly connected with those problems haven't been widely analyzed as a special theme:

- the task of the usage of hovels with lath columns as houses, light huts, and later shacks with half cellars for a very long period (approximately for more than 3 thousand years) in the territories of Southern Aralbuyi;

- the keeping the potential degree of primitive method of making clay dishes in hands which is one of the signs of development degree of material culture;

- the task of later appearance of agriculture and livestock breeding from chronological view point in Khorezm oasis than in other regions of Central Asia and they are leading forms which were considered as superior in the regional production economy;

- the peculiarities of relations between ancient societies, sociable and economical relations, system of society and governing.

From the archeological point of view the learned memorials in Southern Aralbuyi are considered with developed and last stages of the Bronze Age. It is possible to compose the following table generalizing the existing information from scientific literatures.

It is possible to see from the table that forms of economy and works, structures of housing, habit of using stones and bronze in order to make 
instruments, method of making clay dishes in hand are the continuance of cultural traditions formed during Tozabogyop - Amirabad cultures of the late Bronze Age according to their signs. But these traditions were developed on new basis and their some changes in the sights, looking, forms and qualities of housings, instruments, clay dishes, jewelries.

The houses of Tozabogyop culture separately contained half cellars and from this the size of houses are commented with the following measurements: 105-129-132-140 square/meters (the largest ones), 72-80-90 (medium sized), 21-34-62 square/meters (the least ones). In Amirabad memorials there were idenetified some houses which contained 2-3 half cellars among separately situated half cellars, but there is hardly a difference between their sizes, only the territory of one largest house is equal to 165 square/meters, so, the medium depth of cellars comprises $0,4-0,8$ meters ${ }^{1}$.

In the center of half cellars there were identified a big mud-built stove and household pits covered with mud surrounding it.

Things made of bronze were found in a low amount in Tozabogyop culture memorials. They basically consist of knives, sickles, awls, tips of arrows, bracelets, earings and rings and they comprise rare instruments and jewelries ${ }^{2}$. The kinds of bronze fireplaces and arrow tips which belonged to Amirabad culture increased, so there were found stone molds to put bronze sickles and arrow tips. There are some assumptions that bronze goods had been made by regional masters considering the foundation of fixed molds from the memorials of Kukcha 15 and Jonbos 21 of Tozabogyop culture. Blacksmithing was also domestic crafts among pottery-making.

In the southern Okchadarya reservoir the identified Bronze Age locations were not surrounded with defending walls. This shows that there was not the necessity of defending from outer attacks. The locations haven't got a definite plan, houses are situated unorganisedly. According to the writings of M.A. Itina, Bronze Age societies didn't use half cellars for long, they changed their places during the process of the level of water was going down in riverbed branches, so, there existed seasonal houses related to economical form of livestock breeding in pastures.

\footnotetext{
${ }^{1}$ Itina M.A. History of the steppe tribes of the Southern Aral area // Proc. KhAEE - M., 1977. T. Kh. - P. 199, tab. V; C.205, Table. VI.

${ }^{2}$ Itina M.A. Excavations of the burial ground of the Tazabagyab culture Kokcha 3 // MKhE - M., 1961. Issue. V. - P. 72-75, Fig. 23; O your muallif. The history of the steppe tribes ... P. 129, Fig. 67.

Social science and humanities

X. Matyakubov
} 
There was not found any archeological information belonging to farming culture by the middle 2 thousands B.C. in the territory of Southern Aralbuyi and people of Tozabogyop are considered as the most ancient regional farmers. S.P. Tolstov and Y.G. Gulamov stressed that farming appeared in Khorezm oasis during the Bronze Age ${ }^{3}$. Because of B.V. Andrianov's investigations, the prints of ancient farming lands and river channels in Jonbos-Kukcha oasis were found and checked. The size of farming lands (definitely private plots) are 16x10,10x10, $7 \times 7 \mathrm{~m}$, the length of rivers are $150-200$ meters, ${ }^{4}$ but there was not found any seeds of wheat and barley in houses. The private plots were situated near water - on the shores of riverbeds. Perhaps, farmers took their benefit from the wetness of private plot soil at the result of the rise of underground water. It is necessary to emphasize that it is not important to increase farming possibilities during the process of food production by the Bronze Age people of Southern Aralbuyi. Even in the late Bronze Amirabad Age there were not existed wide irrigation constructions in Okchadarya reservoir and worked farm lands were limited.

In comparison, in the south of Central Asia in oasis of enealithic period farming lands which were based on artificial irrigation covers 50-70 hectares ${ }^{5}$. Medium 47-52-71 hectare farm lands were used in different stages in the south of Uzbekistan surrounding Bronze Age Sapallitepa. Hunting also was an important job among farming and livestock breeding in the life of people of Sapallitepa ${ }^{6}$. Farming lands in the Bronze Age in the territories of Northern Afghanistan (Southern Bactria) contained 40-45 hectares and there was not found the prints of wide irrigation constructions ${ }^{7}$.

At his time S.P. Tolstov wrote that there appeared wide irrigation system with developed branches during the last stage of (the $8^{\text {th }}$ and the beginning of the $7^{\text {th }}$ centuries B.C.) Amirabad culture and it is possible to suppose that the existance of this system caused the appearance of slavery relations among primitive societies ${ }^{8}$. M.A. Itina was a supporter of that idea and wrote on the basis of the first results of the archeological investigations

\footnotetext{
${ }^{3}$ Tolstov S.P. Ancient Khorezm. - Moscow: Moscow State University, 1948. - P. 67; Gulyamov Ya.G. History of irrigation of Khorezm from ancient times to the present day. - Tashkent: Fan, 1957. - P. 59.

4 Andrianov B.V. Ancient irrigation systems of the Aral Sea area. - Moscow: Nauka, 1969 - P. 106-109.

${ }^{5}$ Lisytsina G.N. Formation and development of irrigated agriculture in Southern Turkmenistan. - Moscow: Nauka, 1978. - P. 211.

${ }^{6}$ Askarov A. Ancient-agricultural culture of the Bronze Age of the South of Uzbekistan. - Tashkent: Fan. 1977. - P. 120-121, 147..

${ }^{7}$ Sarianidi V.I. Ancient farmers of Afghanistan. - Moscow: Nauka, 1977. - P. $132 .$.

${ }^{8}$ Tolstov S.P. According to the ancient deltas of Oks and Yaksart. - Moscow: IVL, 1962. - P. 75.
}

Social science and humanities

X. Matyakubov 
carried out in the memorial Yakkaparson 2 that during the $9^{\text {th }}$ and $7^{\text {th }}$ centuries B.C. in the culture of Amirabad societies there appeared new sociable formation - passing to slavery system at the end of primitive society. But the indicators belonging to farming lands in Okchadarya reservoir and the size of farming, the degree of the usage of artificial watering lamds with agricultural aim and other factors (total number and territorial density of people) do not serve as the basis for the above narrated conclusions.

The methods of providing with food materials of the society in Southern Aralbuyi which belong to this theme and which is considered as an important function of economical system was not systematically learned enough.

It is possible to come to conclusion that irrigation farming economics was not superior at first in the territories which had been mastered by the people of Tozabogyop considering the origination of them from desert tribes among which Srubnaya and Andronovo cultures spread and migration to the territories of Okchadarya reservoir.

The tribes of Andronovo culture in the Southern Urals were busy with livestock breeding, kair (liman) farming, which was carried out on the lands sometimes made damp by riverbeds, was considered as an subsidiary task in their life'.

According to archeological information, the bones of domestic animals which were found from Tozabogyop culture location are the bones of 60 cows, 349 minor livestock, 17 horses, 2 camels were found. From percental point of view the bones of domestic animals of Amirabad period comprise $28,5 \%$ thick horned livestock, 50\% minor livestock, $18,5 \%$ horses $^{10}$. From it we can see that minor livestock breeding was considered as superior in the composition of domestic animals. It was very comfortable to breed goats and sheep on desert lands. Cows were cared in the pastures surrounding the locations.

The bones of minor livestock were more found among the bones of domestic animals which were found in the Southern Turkmenistan memorials of the Bronze Age and in Zamonbobo location in Lower Zarafshan ${ }^{11}$. They comprise $63.22 \%$ of the total amount of the bones found in

\footnotetext{
${ }^{9}$ Salnikov K.V. Essays on the ancient history of the Southern Urals. -M., 1967. - P. 148-149.

${ }^{10}$ Itina MA The history of the steppe tribes ... S. 185, tab. III, pp. 186-187, Table. IV.

${ }^{11}$ Ermolova N.M. Materials for the study of cattle breeding and hunting in Central Asia in the era of the Eneolithic and Bronze // Ancient civilizations of the East - Tashkent: Fan 1986. - P. 114-115., Gulyamov Ya.G., Islamov U., Askarov Social science and humanities

X. Matyakubov
} 
Sapallitepa, but the weight of cows was comparingly heavier and basically they provided people with milk and meat ${ }^{12}$. So, increasing the number of thick horn cows was a productive form of livestock breeding than minor livestock.

In the south of Central Asia camel-breeding (the second half of the 3 thousands B.C.) and horse-breeding (2 thousands B.C.) developed as separate branches of agriculture ${ }^{13}$. Camels, horses, donkeys were widely used as transports moving on dry land in the Bronze Age. They played a great important role in carrying luggages, passing long distances and in the migration processes ${ }^{14}$.

Bones of domestic camels and horses were found in the Bronze Age memorials of Southern Aralbuyi. They were basically used in household works and as transports. Horses played an important role in the process of seasonal moves of cattle breeders and mastering new territories.

Livestock breeding was an important branch in the economy of Southern Aralbuyi societies as a productive economy. Livestock breeding provided people with meat, milk, wool, and leather goods.

It is necessary to pay attention to hunting in the process of providing the regional society with food. Bones of deers and elks were found in the Bronze Age memorials of Okchadarya reservoir. Hunting these fast running animals was a complex task in the wasteland condition. It is possible to make an assumption that the method of surrounding wild animals was also used besides the actions of single hunters using arrows.

Fish bones were not found in the memorials of Tozabogyop culture. We can make a conclusion that fishing was unconsciously developed during the Bronze Age considering lots of little lakes for fish and the situation of locations on the riverbeds of Okchadarya. As an argument for this conclusion we can offer fishhook made of bronze found in the memorial Barktom 8, it is like a fishhook belonging to Zamonbobo culture ${ }^{15}$.

According to the assumption of M.A. Itina, perhaps eating fish was prohibited during Bronze Age, this behaviour might come out from the

\footnotetext{
A. Primitive culture and the emergence irrigated agriculture in the lower reaches of Zarafshan - Tashkent: Fan, 1966. P. 172 .

${ }^{12}$ Askarov A. Ancient-agricultural culture of the Bronze Age ... S. 119-120.

${ }^{13}$ Ermolova N.M. Remains of mammals of the Bronze Age from the ancient settlement of Altyn-depe // New archaeological discoveries in Turkmenistan. - Ashgabat, 1982. - P. 148-149.

${ }^{14}$ Mavlonov U. Ancient ways in Central Asia. - Tashkent: Akademiya, 2008. - P. 251-254.

${ }^{15}$ Gulyamov Ya. G., Islamov U., Askarov A. Primitive culture ... tab. XVI, Fig. 17.
} 
appearance of fish conviction and imageries of totems ${ }^{16}$. The ancientness of the prints of fish conviction in Southern Aralbuyi was reflected in the ethnographic information ${ }^{17}$.

In our opinion fishing didn't loose its role among hunting wild animals and birds in the life of the Bronze Age societies in Southern Aralbuyi. The works which were connected with mastering existing food products in the nature was developed additionally with productive economy. The existence of lots of fish bones in the lower cultural layers of the location Qanga 2 belonging to Amirabad culture can prove this conclusion.

Household crafts, various house professions and works played an important role in the process of supporting the needs of society. It is necessary to pay attention to the following approaches and tasks in learning their relationship and development:

- identifying the degree of profession and technological peculiarities of production;

- marking the territorial situation of crafts in locations;

- identifying the degree of changing products of household professions and crafts $^{18}$.

The Bronze Age instruments and things in Southern Aralbuyi were produced in household conditions according to their main peculiarities. Household crafts was connected with making stone and bronze instruments and clay dishes. Livestock breeding caused the development of spinning, textile manufacturing and leather production. Members of societies made various instruments and things due to economical branches, life condition and household needs. Creating dishes from mud and instruments from stone in the strap method was not a difficult labor. It is possible to make stone instruments, for example medium sized hand mill which is used in Archeology during 10 hours $^{19}$.

Bronze things were also produced in household condition. Their types hardly changed in the process of 700 years of the development of Tozabogyop and Amirabad cultures. According to M.A. Itina's writings, it is possible to make an assumption that there existed specialized masters who

\footnotetext{
${ }^{16}$ Itina M.A. The history of the steppe tribes ... S. 190-191.

${ }^{17}$ Snesarev G.P. Relics of pre-Islamic beliefs and rites of Uzbeks of Khorezm. - Moscow: Nauka, 1969. - P. 325-330.

${ }^{18}$ Masson V.M. Economics and social structure of ancient societies (in the light of archeological data). - L .: Science, 1976. - P. 59.

${ }^{19}$ Shirinov T. Production tools and weapons of the Bronze Age of the Central Asian Mezhdurechye. - Tashkent: Fan, 1986. - P. 17-18.

Social science and humanities

X. Matyakubov
} 
were busy with producing bronze goods because stone molds were found in a separate house in Yakkaparson location.

In our opinion, the main portion of existing things were the products of household handicraft. Hand made clay dishes were the continuance of primitive traditions according to their quality. According to ethnographical information, making dishes from mud in hands and ripening them on bonfire were women's job for a long time. Farmers, cattle breeders and hunters could make their special instruments in household condition. So, it is not out of the realm of possibility that societies bartered some bronze goods and jewelries.

Therefore, it is necessary to stress that household handicraft products were used at first for the internal everyday needs of members of society. Besides, some products (dresses, carpets, wool and leather) were used in internal and external bartering processes. But there is no written sources about this theme and archeology owns limited possibilities in identifying the amount of producing goods in order to barter.

Considering the peculiarities of archeological materials, there is a supposition that jewelry goods, labour tools and instruments were used $n$ ancient bartering processes ${ }^{20}$. The appearance and development of such form of bartering was marked by people's different location and economical directions. Barter which was based on economical factors appeared because of life needs.

The possibilities of internal and external bartering relations widened At the result of the appearance of transportation objects. There were found copies of wheels of carriages made of mud in the locations of Bayramkazgan, Kukcha 15 and Kukcha 16 of Tozabogyop period ${ }^{21}$. Wheels were invented during Bronze Age in Central Asia and there appeared carts with wheels joined to domestic animals (camel, horse, donkey). This is proved by clay monument of camel and cart, pieces of clay monument carts, horse and camel which were found in Oltintepa in Southern Turkmenistan.

Horse breeding was developed in the Volga territories, Southern Urals, Kazakhstan and the wastelands of western Siberia during Bronze Age and horse usage began to spread widely. Horses played a very imporatnt role in the life of ancient livestock breeders ${ }^{22}$. The borders of livestock breeders'

\footnotetext{
${ }^{20}$ Masson V.M. Economy and social system ... P. 74..

${ }^{21}$ Itina MA History of the steppe tribes ... P. 188.

${ }^{22}$ Смирнов К.Ф. О погребении с конями и трупосожжениях эпохи бронзы в Нижнем Поволжье // СА. - М., 1957. XXVII. - C. 215.

Social science and humanities

X. Matyakubov
} 
location widened because of domesticating horses, new pastures and water sources were mastered, there appeared possibilities to migrate to winter and summer pasturelands 23 .

Southern Aralbuyi was included to the circle of pastureland cultures in which horse breeding was developed. This idea can be proved by horse bones identified in the locations and clay monument of horse found in the memorial Kavat 3.

Needs for the metals like tin and copper increased at the result of the prosperity of bronze metallurgy. Mines of tin and copper were situated in central Kizilkum near Aralbuyi territories ${ }^{24}$. Tin and copper mines were actively mastered by pasture tribes during Bronze Age and raw materials taken from them and cast metal pieces produced at the result of melting metals in the workshops near mines played a big role in the process of internal and external bartering. Transportation tools were used in order to transport luggage in mining affairs. We can suppose that donkeys and camels were considered as heavy luggage lifters among them. According to the writings, donkey was the main luggage carrying transport in Mesopotamia (the middle of the rivers Dajla and Frot) during Bronze Age. Donkey had the ability of carrying the luggage of $60 \mathrm{~kg}$ and walking $35 \mathrm{~km}$ distance in a day.

Archeological materials which were found from houses and locations play an important role in learning the procsses of social relations in the system of family and society. Groups of hunters, fishers and pickers spread in Okchadarya reservoir by the beginning of 2 thousands B.C. they continued their traditions of house building and custom. These traditions are reflected in scoopers, hole pokers, tips of arrows and spears which were made of quartzite and flint belonging to Suvyorgan culture and in the forms of shelters with wood columns.

Even though there is not enough scientific proves, S.P. Tolstov connected the appearance of Suvyorgan culture tribes in Khorezm at the edge of 3 - 2 thousands B.C. with "the new ethnic element which came from flat mountain regions of Iran and neighboring countries" 25 . This approach was criticized in scientific literatures. In the memorial Jonbos 6 belonging to

\footnotetext{
${ }^{23}$ Akishev K.A. Horse nomads of ancient Kazakhstan // Interaction of nomadic cultures and ancient civilizations. Alma-Ata: Science, 1987.-C. 11-12.

${ }^{24}$ Buryakov Yu. The state of metallurgical production in the period of Avesta's emergence // O'zbekiston tarixi. Tashkent, 2001. 3-son. -FROM. 20-22.

${ }^{25}$ Tolstov S.P. In the footsteps of the ancient Khorezmian civilization. - M., 1948. - P. 77-78; Tolstov SP, Itina MA The problem of Suyurgan culture // CA. -M., 1960 №1. -C. 14-35

Social science and humanities

X. Matyakubov
} 
Suvyorgan culture there were found the sprints of large mud-built stove and little mud-built stoves belonging to separate families surrounding the larger one in the shelter formed house. This behavior repeats the location stoves in a shelter belonging to Kaltaminor culture. It is known that during the Bronze Age houses were built with mud wall and unripe bricks in the south of Central Asia, in neighbour regions Afghanistan and Iran. The Southern Aralbuyi societies didn't use those construction materials for a long time.

Regional hunters and fishers who often changed their living places during the Ages of New Stone and early Bronze did not have the necessity for steady houses built of mud walls and unripe bricks. This situation can be commented with natural atmosphere, mastering economy, societies' life condition and their unfamiliarity of leading practice in house building. But during the developed and late Bronze Age, half cellars like a hovel and light huts served as a main form of housing approximately for 700 years in Khorezm oasis, i.e. the behavior of using houses suitable for wasteland livestock breeder tribes was kept.

From the New Stone Age there began to appear wide possibilities of social-economical development and quickening the prosperity of producing power in the southern territories in comparison with the north-eastern territories of the continent at the result of the appearance of production economies in the south of Central Asia. Economical and cultural unevenness in the development of various regions' people strengthened a lot in the New Stone and Bronze Ages.

The above analized information shows that a lot of differences and unevenness was kept in the social and economical development of regional tribes compared to southern regions even at the time when livestock breeding and farming developed in the territories of Southern Aralbuyi at the Lower Amudarya reservoir. This keeping of differences and unevenness for a long time are commented with low spreading of the practical knowledge about new technological invents, economy and handicrafts, building construction and architectural inventories and news in the Bronze Age in Khorezm oasis.

Uneven social and economical development between tribes and people is particular with world historical processes and leading technological and cultural achievements were applied in different territories at the result of increasing of cultural economical relations and migration of people. The researchers stress about that like this, "it is necessary to pay attention to a special lawfulness in the formation of the first and next birth places of 
civilisation connected with step-by-step increasing of the territories in which economical, technological and cultural achievements were spread out".

In the $70 \mathrm{~s}$ of the $\mathrm{XX}$ century V.M. Masson analyzed the task theoretical and methodical role of using archeological information in learning social and economical problems. Social, economical and ecological factors effected the peculiarities of house building in the Bronze Age in Khorezm oasis either. The functions of houses are connected with economical forms, people's life style (settled, half setled, migratory) and natural atmosphere and the size of houses were marked with the number of family members. So, shepherds who were breeding cattle in pasturelands used seasonal light houses of farmers like huts during farming, harvesting and preparing feed and hay reserves.

In Tozabogyop period locations containing separate groups appeared in comparison with the last stages (the existence of single situated shelters belonging to kin societies in vast territories). Researchers wrote that more than 35-40 family members lived together in half cellars the plot of which was more than 100 square/meters. Medium 100 people lived in the Tozabogyop period locations and it is supposed that the number of the people of Yakkaparson 2 location including 19 houses in itself comprised 500-550 persons.

Various scientific and methodical approaches, written sources and ethnographic information are used in the process of learning the tasks of paleodemographical history of Central Asia.

I.M. Dyakov writes that separate families consisted of 4-5 members in the Ancient East being based on the analysis of the family lists in the households of Lagash city ${ }^{26}$. According to the idea of V.M. Masson, G.N. Lisishyna and A.A Askarov, it is possible to comment the family composition of the New Stone, Eneolithic and Bronze Ages with 4-5-6 members ${ }^{27}$.

V.M. Masson stressed that 150-180 persons lived in Joytun memorial of the New Stone Age containing 30 single room houses in Southern Turkmenistan $^{28}$ (S.P. Tolstov wrote that 100-125 kin members lived in the shelter Jonbos 4 of the New Stone Age). According to G.N. Lisishyna's writings the number of Joytun's people contains 120 persons.

\footnotetext{
${ }^{26}$ Dyakonov I.M. The social and state structure of the ancient Mesopotamia. -M .: Ventilation, 1959. - P. 17-18.

${ }^{27}$ Masson V.M. Settlement Jeytun / MIA. - M., 1971. No. 183.-C. 101; Lisitsyna G.N. Formation and development of irrigated agriculture ... P. 69; Askarov A.A. Ancient-agricultural culture of the Bronze Age ... P. 150.

${ }^{28}$ Masson V.M. The settlement of Dzheitun ... P. 101.

Social science and humanities

X. Matyakubov
} 
According A.A. Askarov's idea, medium 154-314-242 people lived in the 8 shopping districts of Sapallitepa during the three stages of the Bronze Age.

Thus we can see that there are different ideas about the number of ancient people in the scientific literatures. The ideas about the composition of a large family in Southern Aralbuyi during the Bronze Age consisted of 35-40 persons are a little discussable. A large family might contain 3-4 little families considering the sociable and economical situation and life condition of the ancient period. There was made a conclusion that a large family containing 4 little families of 20-24 persons in the house fortification Kizilcha belonging to the early Iron Age which was learned in Southern Uzbekistan in Mirshodi oasis. There were identified 15 house-fortresses in Mirshodi oasis and the number of people of them was marked with approximately 300 hundred people ${ }^{29}$.

Large families containing little family members comprised kin societies. According to "Avesta" traditions of kin - "vis" composition included 15 families in itself. In Mirshodi oasis house-fortresses comprise separate groups containing 3-4 houses. It means that they belonged to relative large families and it is not out of the realm of possibility ${ }^{30}$. Separate descendent society members containing large families lived in houses learned in Yakkaparson 2 memorial of Amirabad culture too. Considering the total number of people containing 500-550 people which was supposed by M.A. Itina, Yakkaparson is like the centre of the tribe. The above shown indicators about the number of people are relative at a special degree. It is considered that medium 17002400 people lived in Geoksur location (Southern Turkmenistan) in the Eneolithic Age the size of which is larger than Yakkaparson location ${ }^{31}$.

Archeological information belonging to Tozabogyop culture shows the proprietary and social equality of the society members. Hand made clay dishes of the same quality, stone and bronze instruments were found in houses. Researchers paid attention to the materials of half cellars which are differentiated by their size in Kukcha 15 memorial. Bones of two cows, six minor cattle, pig, camel and horse were found in that house. There was a question put forward about the appearance of large patriarchal families separated with their position at the last stage of primitive society's history,

\footnotetext{
${ }^{29}$ Sagdullaev A.S. Manors of ancient Bactria. - Tashkent: Fan, 1987. - P. 62.

${ }^{30}$ Sagdullaev A.S. Manors of ancient Bactria ... C. 70.

${ }^{31}$ Lisitsyna G.N. Formation and development of irrigated agriculture ... P. 73.

Social science and humanities
}

X. Matyakubov 
because such amount of livestock bones were not found in other houses. So, there was made a conclusion that women were buried separatedly according to their position on the basis of the 5 bronze bracelets found among the burial utensils in the grave of a woman of Kukcha 3 memorial of the Bronze Age. But there was not observed any sign of social differentiation or proprietary inequality in the quantity of household utensils and kinds of jewelry in the same houses with half cellars belonging to separate large families.

Large patriarchal families containing several little families owned their half cellar houses, private property, private plot, livestock, food reserve and productive utensils during the stages of development of Tozabogyop and Amirabad cultures. Such families continued descendent traditions of primitive society comparing with ethnographical information. They were united by common labor, the law equal working for everybody for the prosperity of family, common property, labor instruments and food reserve, common houses and life condition. Besides, it is necessary to mention the appearance of large family societies of the Bronze Age which could economically provide themselves in Khorezm oasis.

According to the information in "Avesta", a large family was governed by the owner of the house - father at the old age, such families were united to the society of kinsmen, elder grandfather was called "the owner of kinsmen", "wispat" 32 . It is worth to mention one more time that the sociable relations of large families of the Bronze Age in Southern Aralbuyi were marked by the peculiarities of kin system. It is possible to suppose the intentions of ancient society members to join in order to solve problems which appeared from their internal and external relations. Controlling and regulating internal relations of societies became the function of large family rulers and elder grandfathers. Carrying out household affairs was based on the activity of organizational management.

Learning ancient sociable system and problems of social relations on the basis of archeological information is a very difficult task. But we have to use this approach because of the inexistence of written sources. Existing information is the basis to note the following ideas:

- the Bronze Age locations of Khorezm oasis were not surrounded by defending walls. This situation shows that there was not the necessity for defending from outer attacks;

\footnotetext{
${ }^{32}$ Masson V.M. To the question of the social structure of ancient Central Asia // History, archeology and ethnography of Central Asia. -M .: Science, 1968. - P. 92-93.

Social science and humanities

X. Matyakubov
} 
- there were not found sociable buildings and places of worship connected with belief and fulfilling customs;

- learned ancient graves consist of plain cavities, the burial utensils taken from them were the basis for the conclusion about sociable equality;

- there was not found any building for keeping agricultural goods and food reserves;

- the prosperity of household handicrafts was mainly directed to provide the internal needs of kin societies.

We know that the appearance of production economy, copper and bronze metallurgy caused the appearance of excessive goods in different continents ${ }^{33}$. In our opinion, there was not a comfortable condition to excess agricultural goods and handicraft utensils for regional large families and kin societies because of not enough development of production power during the Bronze age in Southern Aralbuyi. In this point it is necessary to mention one more time the condition of uneven social and economical development of the tribes belonging to the history of the Bronze Age.

Production relations of the Bronze Age in the south of Central Asia (especially in the territories of Margiyona and Bactria) were soon developed and effected social and economical processes. At the result of rapid development of these processes building construction, metallurgy, pottery making, jewelry-making, spinning and textile became a special profession.

In the last years learning the tasks of economical relations in Central Asia and process of appearance and development of sociable governing was observed by U.I. Abdullaev. The researcher widely analyzed the results of learning primitive society's sociable and economical relations which was based on mastering and productive economy on the basis of historical literatures, ethnographical and archeological information. Considering existing approaches and scientific view points, it is possible to suppose that sociable governing based on the demands of primitive society was developed in Khorezm oasis because of the superiority of the traditions and customs of kin system in the history of the Bronze Age. As we mentioned above, the rulers of large families and elder grandfathers played an important role in the regularity of sociable governing. The functions of planning, organizing, regulating, controlling and conforming relations between societies, solving discussable tasks were vital actual necessities.

\footnotetext{
${ }^{33}$ Primitive society. The main problems of development. -M .: Science, 1975. - P. 88.
} 
The signs of the Bronze Age society in Southern Aralbuyi are as following on the basis of analyzed information:

\section{Table 1}

The signs of the Bronze Age society in Southern Aralbuyi

\begin{tabular}{|c|c|c|c|}
\hline Date & $\begin{array}{l}\text { Life condition and } \\
\text { economical signs }\end{array}$ & $\begin{array}{l}\text { Sociable } \\
\text { signs }\end{array}$ & Territorial signs \\
\hline $\begin{array}{l}15^{\text {th }-10^{\text {th }}} \\
\text { centuries } \\
\text { B.C. } \\
\text { (Tozabogyo } \\
\text { p culture) }\end{array}$ & $\begin{array}{l}\text { Settled, half } \\
\text { setled, seasonal } \\
\text { migratory. Livestock } \\
\text { breeding, farming and } \\
\text { hunting. Common } \\
\text { houses and property. } \\
\text { Household utensils, } \\
\text { labor instruments, } \\
\text { private plot, cattle and } \\
\text { food reserve. }\end{array}$ & \begin{tabular}{l}
\multicolumn{2}{c}{ Large } \\
families. Kin \\
society's \\
turning up \\
into tribes. \\
Customs and \\
traditions of \\
kin system, \\
sociable \\
governing.
\end{tabular} & $\begin{array}{l}\text { The location of } \\
\text { society members in a } \\
\text { special territory. Using } \\
\text { water sources, farms } \\
\text { and pastures of the } \\
\text { territory an } \\
\text { economical aim. } \\
\text { Mastering existing } \\
\text { natural goods. }\end{array}$ \\
\hline $\begin{array}{l}9^{\text {th }}-8^{\text {th }} \\
\text { centuries } \\
\text { (Amirabad } \\
\text { culture) }\end{array}$ & $\begin{array}{l}\text { Settled, half } \\
\text { setled, half migratory. } \\
\text { Livestock breeding, } \\
\text { farming, hunting and } \\
\text { fishing. Houses, } \\
\text { private plots, cattle, } \\
\text { food reserves and } \\
\text { productive } \\
\text { instruments belonging } \\
\text { to large families. }\end{array}$ & \begin{tabular}{l}
\multicolumn{2}{c}{ Large } \\
families, kin \\
societies, \\
tribes. Kin \\
system, \\
sociable \\
governing.
\end{tabular} & $\begin{array}{l}\text { The location of } \\
\text { different kin members } \\
\text { in the territory. Using } \\
\text { existing natural } \\
\text { resources (water, land, } \\
\text { pasture, world of } \\
\text { cattle and plant, raw } \\
\text { material reserves) in } \\
\text { the territory in order } \\
\text { to produce and } \\
\text { master. }\end{array}$ \\
\hline
\end{tabular}

Sociable, economical and cultural development of the tribes of the late Bronze Age of Amirabad culture are commented with changes. Appearance of larger locations and houses containing 2-3 half cellars, increasing the role of horse breeding together with cow and minor livestock breeding, changing of clay dishes from formal, number and qualitative view points, rapid increasing of bronze instruments and utensils, melting copper and tin materials, appearance of work shops connected with producing cast bronze instruments using stone molds on the basis of copper and tin mixture are among the above mentioned changes. 
So, it is necessary to mention the beginning of complexity of ethnic processes in the archeological materials belonging to the late Bronze Age. Invention of big mausoleums in Lower Syrdarya reservoir in Nourthern Aralbuyi (Northern Tagisken) and learning the burial ceremonies of elder grandfathers and leaders of migratory livestock breeder tribes in them are the plain expression of sociable changes in the $9^{\text {th }}-8^{\text {th }}$ centuries B.C.

As a conclusion it's necessary to stress that any person or special common government who had carried out ruling affairs gaining a special position in the kin society of people in Khorezm oasis was not known by the $7^{\text {th }}$ century B.C. sociable governing connected with processes of fulfilling vital necessary needs of society members was on the upper position. The most important tasks were solved in common meetings of kin representatives. Kin rulers and tribe leaders were selected in the meetings of the representatives of large families and kin societies.

The selection of leaders in the system of kinsmen - tribe was connected with their personal ethical peculiarities and practical knowledge.

The researchers' conclusion (S.P. Tolstov, M.A. Itina) in which the history of Khorezm oasis during the $9^{\text {th }}-8^{\text {th }}$ centuries B.C. is the stage of passing to new sociable formation - slavery system has not been proved. 


\section{References}

1. Askarov A. Ancient-agricultural culture of the Bronze Age of the South of Uzbekistan. - Tashkent: Fan. 1977.

2. Andrianov B.V. Ancient irrigation systems of the Aral Sea area. Moscow: Nauka, 1969.

3. Gulyamov Ya.G. History of irrigation of Khorezm from ancient times to the present day. - Tashkent: Fan, 1957.

4. Sarianidi V.I. Ancient farmers of Afghanistan. - Moscow: Nauka, 1977.

5. Itina M.A. Excavations of the burial ground of the Tazabagyab culture Kokcha 3 // MKhE - M., 1961.

6. Tolstov S.P. Ancient Khorezm. - Moscow: Moscow State University, 1948.

7. Tolstov S.P. According to the ancient deltas of Oks and Yaksart. Moscow: IVL, 1962.

8. Lisytsina G.N. Formation and development of irrigated agriculture in Southern Turkmenistan. - Moscow: Nauka, 1978. 